\section{1. 夢は小さすぎた}

昭和39年秋のことです．自動車技術会から「世界にお ける日本の自動車業界の地位」の特集を 1 月号にするか ら，乗用車部門の記述をしてほしいと依頼をうけまし た. 正月号に掲載されるというので，最後に筆者の夢を 㪚ら言われている「 1 富士， 2 鷹，3なすび」で，以 下のようにむすびました1).

眺めては富士山のごとく優雅で雄壮なスタ イルの車が，動き出せば鷹のような機敏な 機能を発揮する.

その車からはなすびのような底光りのする 光沢を放散する。

機能的には国際レベルのトップをいく．し かも品質管理のすみずみまで行き届いた工 程でつくられた製品は高い信頼性をもつ.

量産では, 米国につぐ第 2 位, 価格では世 界のどの国にも負けない．

自動車の売れるところ日本商品が「どとう」 のように続く $\cdots \cdots . .$.

自動車立国の絵巻物ははてしない.

表 1 世界主要国の自動車生産台数（1970年）

\begin{tabular}{|c|c|c|c|c|c|}
\hline 国 & 別 & 総生産台数 & うち & $\begin{array}{c}\text { うちトラッ } \\
\text { ク・バス }\end{array}$ & 前年比 \\
\hline 米 & 国 & $8,281,857$ 台 & $6,549,058$ & $1,732,799$ 台 & $\begin{array}{r}\% \\
\ominus 18.8\end{array}$ \\
\hline 日 & 本 & $5,289,157$ & $3,178,708$ & $2,110,499$ & $\oplus 12.7$ \\
\hline 西 & 独 & $3,842,247$ & $3,527,864$ & 314,383 & $\oplus 6.6$ \\
\hline フラ & Uス & $2,750,086$ & $2,458,038$ & 292,048 & $\oplus 11.8$ \\
\hline 英 & 国 & $2,098,500$ & $1,641,000$ & 457,500 & $\ominus 3.9$ \\
\hline イタ & ア & $1,854,252$ & $1,719,715$ & 134,537 & $\oplus 16.2$ \\
\hline カ & ダ & $1,189,453$ & 938,219 & 251,234 & $\ominus 11.9$ \\
\hline スウ & ェーテ & ت゙ン 310,141 & 278,971 & 31,170 & $\oplus 14.6$ \\
\hline ソ & 連 & 916,000 & 344,000 & 572,000 & (†) 8.2 \\
\hline
\end{tabular}

出所 : 各国自工会資料, World's Automotive Reports, ソ連東欧貿易調査月報より作成

\footnotetext{
* 株式会社豊田中央研究所

（正468 名古屋市昭和区欠方 2-12）
}

当時私はトヨタ自動車の常務をしていました．昭和39 年のわが国の自動車生産は 170万台，フランスを抜いて 米，英，独に続いて，第 4 位に進出した年であり，会社 別では，トヨタ，日産はそれぞれ43万台，35万台を生産 し，世界第11位，第12位といった状況でありました。現

表 2 世界企業別生産台数

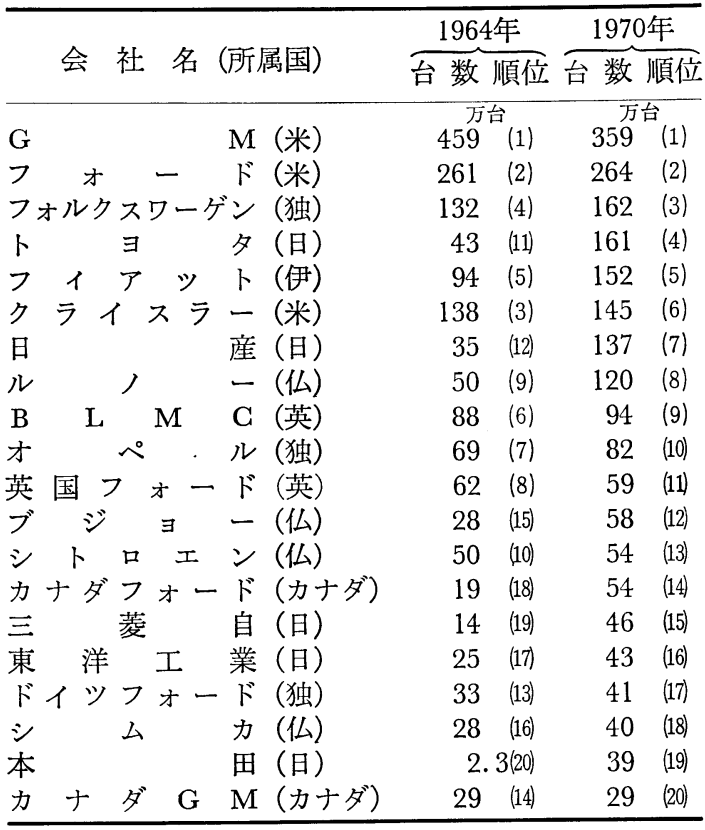

出所: モーターファン

在, 国としては生産第 2 位, 会社別ではトヨタ 4 位, 日 産 6 位の状沉にまで進展しました。はてしないはずであ った私の「自動車立国の絵巻物」は，ほぼ完成に近いの であります．私などの描く夢というものがいかに小さい ものであり, 現実の方がはるかに急速度で進展すること をひしひしと身をもって感じている次第であります。

\section{2. 自動車工業の現状}

\section{1 越えてきた道}

今越えてきた道をふり返ってみますと，何と急な坂で 
あったことかと，しみじみ感ずるのであります．沢山の 問題を抱え，汗だくの多忙さの連続でありました．図 1 はトヨタの生産扔よび輸出の台数の上梨を示したもので あります．過去に小さい波はありましたが，回帰線のよ うな順調な伸び方をして現在に至っており，あとで述べ ますように，行く先にいかようなきびしいものがあろう とも，私はこの曲線に添って，更に上昇を続けうるもの と確信しております。

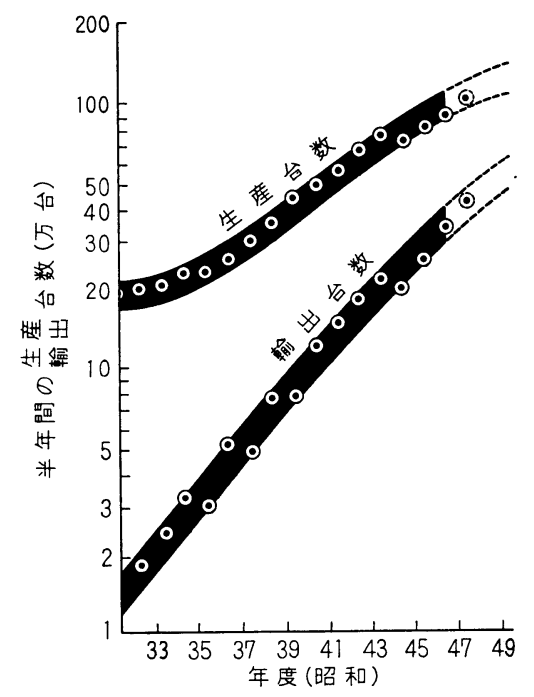

図 1 トヨタ自動車KKにおける生産輸出

輸出につきましては，世界経済大国がいずれも自動車 を1位にしていますのに，わが国は鉄鋼，造船の次で， お前たちは急けているのではないかとおしかりをいただ きゔめであったのが，最近になってようやく軌道に乗っ てきた次第であります。

\section{2 生産量の増加と生産性の向上}

今日, 自動車工業が発展した理由にはいろいろの理由 があると思います．たとえば，ゴムメーカーが非常に安 くていいゴム製品を供給してくれたとか, 部品工業が品
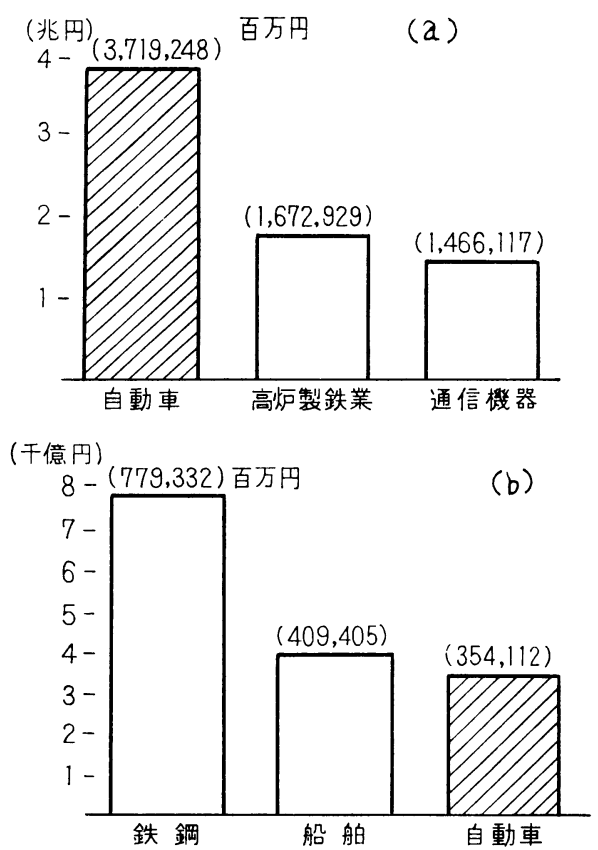

図 2 (a) 工業生産高ベスト 3（1968年） 資料：通産 省「工業統計速報」 (b) 輸出高ベスト 3（1969年） 資料：大藏省「貿易統計」

質管理をすみずみまでゆきわたるようにして，品質確保 をしたとか，設計上の優位とかいろいろありますが，私 はここで生産性の向上をあげてみたいと思います。

生産台数が増加しますと, 1 人当り生産が増加しま す.そのトヨタにおける状況を示したのが図 3 でありま す．日本では量産がいかに生産性を向上させるかも示す ものであります．この数字の国際比較は表 3 に示しまし た.

むろん，欧米の自動車会社で，トヨタのように自動車 以外の製品は皆無といった会社はありませんし，後に示 すように，外注を一番多く使っているのがトヨタですの で，この数字そのものは大きな意味があるとも思いませ

表 3 世界自動車メーカー 従業員 1 人当り年間生産台数ならびに売上額（1968）

\begin{tabular}{|c|c|c|c|c|c|}
\hline & 生産台数 & 売上高 & 従業員 & 1 人当り台数 $/$ 年.人 & 1 人当り売上 万円 $/$ 人・年 \\
\hline G & 542万台 & 81,619億円 & 75.7 万人 & 7.2 & 1,100 \\
\hline フォード & 304 & 50,670 & 41.5 & 7.3 & 1,220 \\
\hline クライスラー & 176 & 7,550 & 23.1 & 7.6 & 1,160 \\
\hline $\mathrm{V} \quad \mathrm{W}$ & 155 & 7,741 & 10.5 & 14.8 & 720 \\
\hline フィアット & 139 & 5,297 & 15.8 & 8.8 & 490 \\
\hline$卜 \quad \exists \quad$ タ & 110 & 5,297 & 3.4 & 82.4 & 1,550 \\
\hline 日 & 98 & 4,878 & 4.9 & 22.3 & 1,120 \\
\hline
\end{tabular}

資料：各社 Annual Report, 日銀外国経済統計季報, 自動車海外情報, その他 


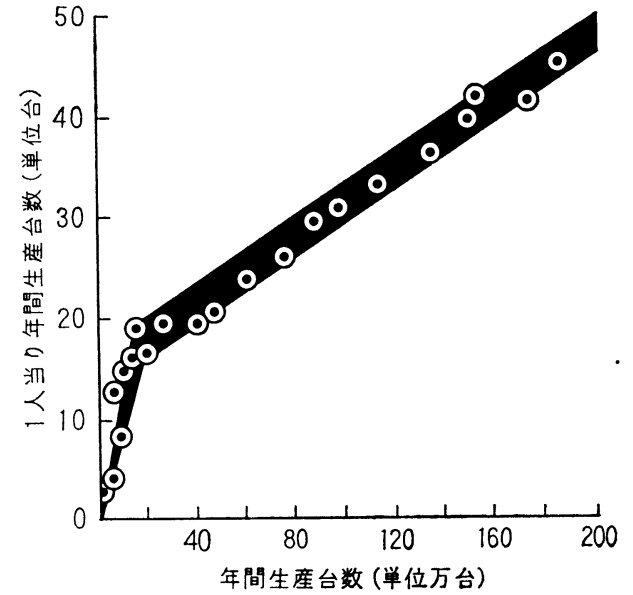

図 3

ん. 比較的対比できるのはフォルクスワーゲン社ですの で，それらと対比してみてもかなり大きな值となってい ます。なおトヨタは販売部門を分離していますので，15 \%位高目に出ております。 また，台数比較でなしに，1 人当り年間売上高も同時に示しました.

この表は各国比較であり，1968年の古い值になってい
ますので，その後のトヨタの值を図 4 に示しました．現 在では 1 人当り生産台数は 44.5 台／人・年，売上は 2,348 万円／人・年となっています.

\section{3 日本自動車工業の特質}

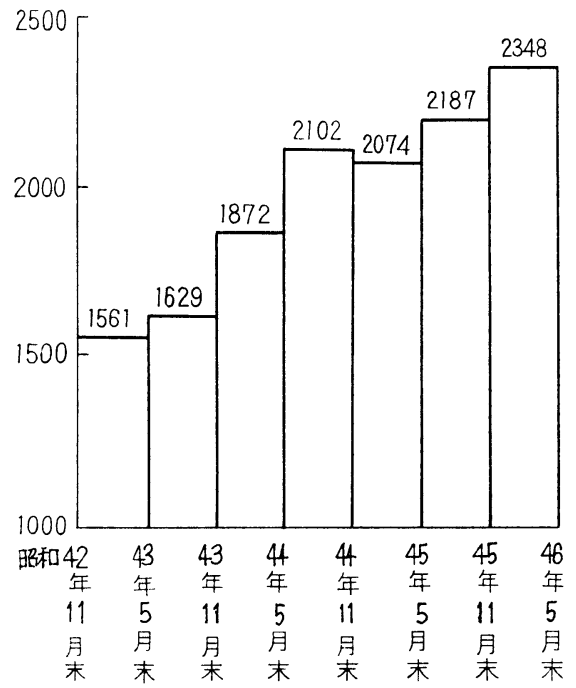

図 4 年間 1 人当り売上 (万円/人・年) 表 5 主 要 部 品 内 外 製

\begin{tabular}{|c|c|c|c|c|c|c|c|c|c|c|c|c|c|}
\hline 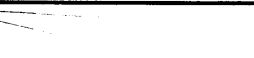 & 国 & & $ア$ & メリ & 力 & イギリス & 西 & 独 & イタリア & フランス & 日 & 本 & \\
\hline 部 品 名 & メーカー & G & M & フォード & $\begin{array}{l}\text { クライ } \\
\text { スラー }\end{array}$ & $\mathrm{BMC}$ & $\mathrm{V}$ & W & $\begin{array}{l}\text { フィア } \\
\text { ット }\end{array}$ & ルノー & トヨタ & 日 & 産 \\
\hline 1 & ヤ & & < & $x$ & $\times$ & $x$ & & $x$ & $x$ & $x$ & $x$ & & K \\
\hline バ ッ テ リ & - & & 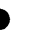 & 0 & $x$ & $x$ & & $x$ & $x$ & $x$ & $x$ & & x \\
\hline ベ ア リ ン & グ & & 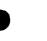 & 0 & $x$ & $x$ & & $x$ & $x$ & 0 & $x$ & & x \\
\hline ガ ラ & ス & & < & 0 & 0 & $x$ & & $x$ & & $x$ & $x$ & & $x$ \\
\hline 電＜wide>装 & 品 & & 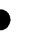 & 0 & $x$ & $x$ & & $x$ & & $x$ & $x$ & & x \\
\hline ラ ジ エ タ & - & & 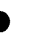 & 0 & 0 & 0 & & $x$ & $x$ & $x$ & $x$ & & < \\
\hline ショックアブソバ & & & 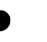 & 0 & 0 & $x$ & & $x$ & 0 & $x$ & $x$ & & < \\
\hline 軸 受 メ 夕 & ル & & 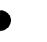 & $x$ & 0 & $x$ & & $x$ & $x$ & $x$ & $x$ & & < \\
\hline ディスクホイー & ール & & 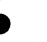 & 0 & $x$ & $x$ & & D & 0 & $x$ & $x$ & & $x$ \\
\hline ガ ス ケ ッ & ト & & x & $x$ & $x$ & $x$ & & $x$ & $x$ & $x$ & $x$ & & K \\
\hline シャシーバ & ネ & & 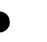 & 0 & - & $x$ & & 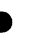 & 0 & 0 & $x$ & & x \\
\hline 計 & 器 & & 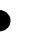 & ○ & $x$ & $x$ & & $x$ & $x$ & $x$ & $x$ & & 火 \\
\hline シールドビー & ム & & 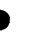 & $x$ & $x$ & $x$ & & $x$ & & $x$ & $x$ & & < \\
\hline エンジンバル & ブ & & < & $x$ & $\times$ & $x$ & & 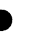 & $x$ & $x$ & $x$ & & < \\
\hline キャブレタ & - & & 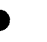 & 0 & $x$ & $x$ & & $x$ & 0 & $x$ & $x$ & & < \\
\hline フ ィ ル タ & - & & 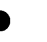 & $\bullet$ & $x$ & & & & & & $x$ & & K \\
\hline ブレ ー & キ & & 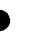 & $x$ & $x$ & $x$ & & $x$ & 0 & $x$ & $x$ & & 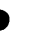 \\
\hline ピストンリン & グ & & x & $x$ & $x$ & $x$ & & $x$ & $x$ & 0 & $\times$ & & $<$ \\
\hline ワイヤハーネ & ス & & 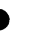 & 0 & $x$ & $x$ & & $x$ & $x$ & $x$ & $x$ & & $<$ \\
\hline シ $\quad-$ & ト & & 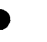 & 0 & 0 & 0 & & 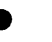 & & & $x$ & & 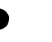 \\
\hline 塗 & 料 & & < & 0 & $x$ & $x$ & & $x$ & $x$ & $x$ & $x$ & & < \\
\hline
\end{tabular}

資料：諸資料より作表

はん例 $\bigcirc$ : 内製 $\times$ : 外製 空欄：不明

注）1. でも一部外注に依存する場合あり。（内製との競争）

2. 電装品とはスターター，ゼネレター，オルタネター，レギュレター，イグニッションをいう. 
表 4 付加価值 /売上高（1968年）

\begin{tabular}{|c|c|c|c|}
\hline G & & $M$ & $55 \%$ \\
\hline フ & - & ド & $42.5 \%$ \\
\hline ク & ライス ラ & - & $41 \%$ \\
\hline V & & $\mathrm{W}$ & $28 \%$ \\
\hline フ & $ア$ & ト & $45 \%$ \\
\hline ト & $\exists$ & 夕 & $25 \%$ \\
\hline
\end{tabular}

付加価値 $=$ 税引後利益十減価償却十労務費 + 值接税 とした

資料：実業の日本 44 年 8 月号

自動車工業の関連分野は広大である.わが国の自動車 工業の特色の一つは，わが国の自動車メーカーの付加価 值がきわめて低いことであります．部品を外注していま す状況を表 5 に示します.ご覧いただけばわかるよう に，トヨタはどこよりも外注部品が多いのであります。 この状況からみますと, 今日欧米では自動車産業の興亡 が国家繁栄に直接大きくひびくといっていますが，日本 ではさらに大きな影響を持つといえます．自動車が不況 になると GMが傾く，GMが傾けばアメリカが傾く，ア メリカが傾けば，世界が傾くといわれますが，この筆法 を使いますと，トヨタが傾けば日本が傾くことは，GM がアメリカに対するよりもっとひどい影響があるように も思います。“自動車工業よ! どこへゆく”は私ども の重大関心事でありますと同時に，国民にも重大関心事 であると確信しております。

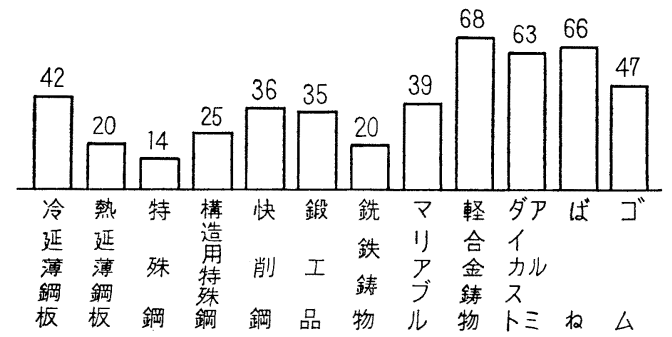

図 5 自動車工業の関連産業と資材消費割合（\%) 資料：通産省機械統計月報他

図 5 は自動車が関連産業と資材にどれほどの割合を占 めているかを示してあります。この図ではゴムは $47 \%$ に なっております。

\section{4 自動車工業とゴムならびにプラスチックエ業}

今日はゴム協会の皆様にお話をするというので，ふだ んはゴムのこととあまり密接ではございませんが，ゴム のことを少し調べてみました，そしたらいろいろなこと がわかりましたが，これは皆様の方がよくご存知ですの で，一つだけ申し上げます．表 6 は皆様ご承知の合成ゴ ム生産の世界序列ですが，米，日，西ドィッ，フラン
表 6 合成ゴムの各国別生産量（1969年）

(単位：トン)

\begin{tabular}{ccccc} 
米 & & & 国 & $2,286,274$ \\
日 & & & 本 & 526,480 \\
西 & ド & イ & ツ & 291,677 \\
フ & ラ & ン & ス & 274,965 \\
英 & & & 国 & 272,993 \\
オ & ラ & ン & ダ & 213,533 \\
カ & \multirow{2}{*}{ ナ } & ダ & 198,811 \\
イ & タ & ア & 135,000 \\
ブ & ラ & ジ & ル & 61,671 \\
チェコスロバキア & 40,000 \\
\hline
\end{tabular}

資料：'Rubber Statistical Bulletion' (I.R.S.G)

ス，英国という序列が，自動車の生産の序列と全く同じ ことを知りました。これは私には大変な驚きでした。図 6 は自動車と合成ゴムの各国別生産の相関を示したもの であります．図７には，米国における自動車のプラスチ

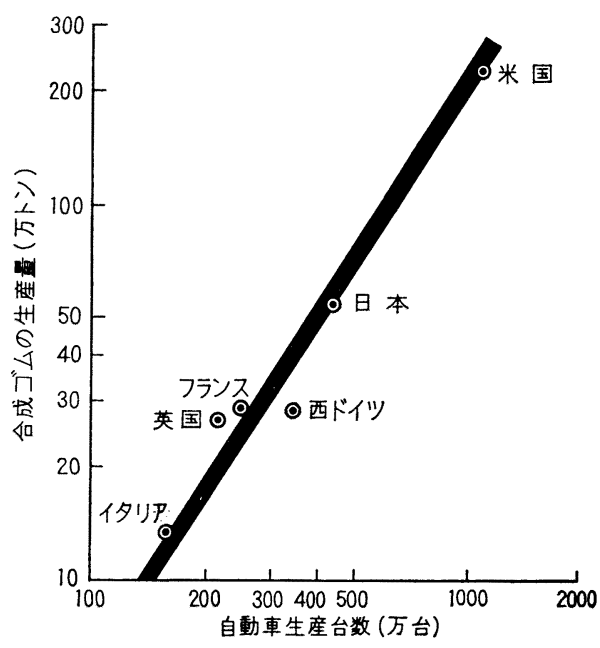

図 6 年間合成ゴムの生産量と自動車生産台数 （1969年）

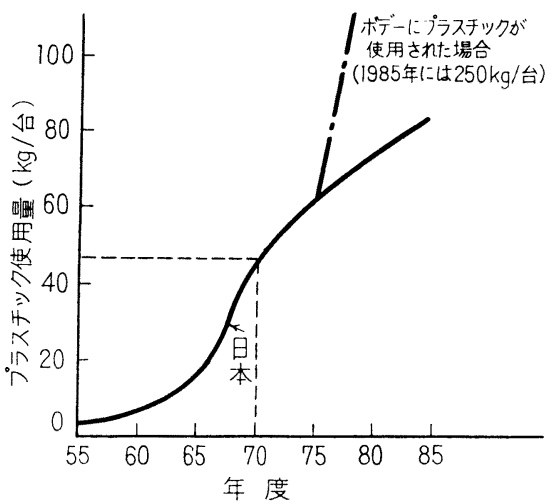

図 7 米国自動車のプラスチック使用量の実績と予測 
三

表 7 プラスチック化が予想される自動車部品と問題点

\begin{tabular}{|c|c|c|c|c|c|c|c|}
\hline No. & 品 & $\begin{array}{l}1 \text { 個 当 }{ }^{y} \\
\text { 重量 }(\mathrm{g})\end{array}$ & $\begin{array}{l}\text { 原料プラ } \\
\text { スック }\end{array}$ & 外 & $\begin{array}{l}\text { プラスチック } \\
\text { 化のメリット }\end{array}$ & 問 題 点 & 技 \\
\hline 1$\}$ & $\begin{array}{l}\text { クーリングファ } \\
\text { ン }\end{array}$ & $150 \sim 200$ & ポリプロピレン & $\begin{array}{l}\text { (英)ナイロン } \\
\text { (米)プラスチ } \\
\text { ック製多い }\end{array}$ & $\begin{array}{l}\text { - 形状の自由度 } \\
\text { - 馬力損失小 } \\
\text { - 騒音小 }\end{array}$ & $\begin{array}{l}\text { ・強度が若干 } \\
\text { 不足 } \\
\text { ・而熱性 }\end{array}$ & \\
\hline 2$\}$ & $\begin{array}{l}\text { ファンシュラウ } \\
\text { ト }\end{array}$ & 400 & $\begin{array}{l}\text { ポリプロピレン } \\
\text { 高密度ポリエチ }\end{array}$ & $\begin{array}{l}\text { (米)少し実用 } \\
\text { 化 }\end{array}$ & $\begin{array}{l}\text { - 形状の自由度 } \\
\text { - 軽量化 }\end{array}$ & $\begin{array}{l}\text { ・現状では鋼製 } \\
\text { よりやや高い }\end{array}$ & \\
\hline 3$\}$ & $\begin{array}{l}\text { エア・クリーナ } \\
\text { ケース }\end{array}$ & $?$ & $\begin{array}{l}\text { ポリプロピレン } \\
\text { (耐熱性のため) }\end{array}$ & & $\begin{array}{l}\text { •消音性 } \\
\text { ・軽量化 }\end{array}$ & ・耐熱性 & \\
\hline 4 & $\begin{array}{l}\text { ホイールキャッ } \\
\text { プ }\end{array}$ & $\left(\begin{array}{l}500 \\
\sim 800 \\
\times 4\end{array}\right)$ & $\begin{array}{l}\text { 塩ビ・ポリエチ } \\
\text { ポリプロピレン } \\
\text { F RP }\end{array}$ & $\begin{array}{l}\text { (英) 1970年 } \\
10 \% \text { A B S }\end{array}$ & $\begin{array}{l}\cdot \text { ・コスト低下 } \\
\text { ・軽量化 }\end{array}$ & $\begin{array}{l}\cdot \text { - 外観 } \\
\text { ·表面処理 } \\
\text { • 取り付け方 }\end{array}$ & $\begin{array}{l}\text { ・パブリカで実 } \\
\text { 施 } \\
\text { ・セリカで実施 }\end{array}$ \\
\hline 5 & 燃料タンク & $3000 \sim 4000$ & $\begin{array}{l}\text { 高密度ポリエチ } \\
\text { ポリプロピレン } \\
\text { ナイロン }\end{array}$ & $\begin{array}{l}\text { (英) } 1970 \text { 年 } \\
\text { 数\% } \\
1975 \text { 年 } \\
\text { 数 } 10 \%\end{array}$ & $\begin{array}{l}\text { ・形状の自由度 } \\
\text { ・コスト低下 } \\
\text { ・軽量化 } \\
\text { ・耐衝撃性 } \\
\text { ・耐食性 }\end{array}$ & $\begin{array}{l}\text { ・大量生産で } \\
\text { ないとかえっ } \\
\text { て高くなる } \\
\text { ・低沸点物が } \\
\text { むれる }\end{array}$ & $\begin{array}{l}\text { - 回転成形法 } \\
\text { - 中空成形法 }\end{array}$ \\
\hline 6$\}$ & $\begin{array}{l}\text { ラジエータグ } \\
\text { リル }\end{array}$ & $1000 \sim 2000$ & A B S & $\begin{array}{l}\text { (米)はプラス } \\
\text { チック多い }\end{array}$ & - 形状の自由度 & & $\begin{array}{l}\text { ・クラウン，コ } \\
\text { ロナで実施ずみ }\end{array}$ \\
\hline 7 & $\begin{array}{l}\text { ボディ } \\
\text { (4 項参照) }\end{array}$ & $\begin{array}{l}200,000 \\
\text { 以上 }\end{array}$ & $\begin{array}{l}\text { F R P } \\
\text { A B S } \\
\text { 強化フェノール }\end{array}$ & $\begin{array}{l}\text { (米)M F G 社 } \\
\text { のコルベット } \\
\text { に採用 }\end{array}$ & $\begin{array}{l}\text { •軽量化 } \\
\text { •コスト低下 } \\
\text { •形状の自由度 }\end{array}$ & $\begin{array}{l}\text { - 生産技術 } \\
\text { 全般に問題点 } \\
\text { 多い. }\end{array}$ & 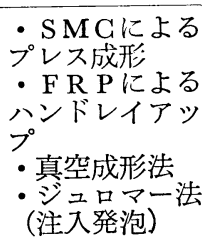 \\
\hline
\end{tabular}

ック使用量の実績と予測を示します。表 7 はプラスチッ ク化を予想される自動車部品と問題点をかかげましたの でこご一覧いただきたいと存じます。

\section{3. 自動車をとりまく環境}

環境問題と安全問題のために，アメリカは非常にきび しい法規をつぎつぎに打出しています。大気污染問題に ついては，ミッキー法案といらむずかしいものが確定的 に法案になりそうであるし，安全問題については，これ からどのような法が出るか予測しがたい，フォード社の メリルは“われわれは爆弾の上に腰かけているようなも のである”と述べて打ります．しかも反自動車論も一部 から唱えられている現状であり，資本は自由化され，G $\mathrm{M}$ ，フォード，クライスラーは相次いで日本に拠点を作 ることに成功し，そのうえ自動車には各種の税がかかっ ており，八方ふさがりであります。

\section{4. 大気污染とその対策}

\subsection{0 年代から 70 年代への変貌}

60年代は経済的な豊かさを求めた時代であったが，70 年代に人間的な豊かさを求める時代といわれます，経済
成長のひずみとして生れた公害問題は，こうした人間的 な豊かさを追求するにあたって，ぜひとも解決しなけれ ばならない70年代の重要な課題の一つであります。（表 8 参照)

表 8 60年代から70年代一の変貌

\begin{tabular}{|c|c|c|}
\hline & '60 年 & 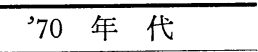 \\
\hline 価 值 基準 & $\begin{array}{l}\text { GN P } \\
\text { 経済成長率 }\end{array}$ & 新しい福祉社会 \\
\hline 人々の欲求 & 経済的な豊かさ & 人間的な豊かさ \\
\hline 企業への課題 & $\begin{array}{l}\text { 利潤の追求 } \\
\text { 国益への奇与 }\end{array}$ & $\begin{array}{l}\text { 永続的な発展 } \\
\text { 社会との調和 }\end{array}$ \\
\hline $\begin{array}{l}\text { 自動車企業の } \\
\text { 責任 }\end{array}$ & $\begin{array}{l}\text { より良い, より安 } \\
\text { 、移動手段, 輸送 } \\
\text { 手段の提供 }\end{array}$ & $\begin{array}{l}\text { より良い移動手段, } \\
\text { 輸送手段の提供 } \\
\text { 自動車をとりまく交 } \\
\text { 通環境改善への協力 }\end{array}$ \\
\hline
\end{tabular}

\section{2 公害問題は多種多様でその原因は複雑}

自動車に関倸の深い大気污染についても非常に複雑で あるが，これを大きく分けると広域的大気污染（スモッ グなど）と，局地的大気污染（一酸化炭素污染，鉛污染 など）とに分類されます。

\section{3 スモッグ}

広域的大気污染であるスモッグは，工場や火力発電所 
の排煙, ビルの暖房, 塺芥の焼却などから排出される亜 硫酸ガス $\left(\mathrm{SO}_{2}\right)$ ，すす，粉塵などを主原因としています。 そのほかに，ロサンゼルスに代表される光化学スモッグ があります。

光化学スモッグは，ロサンゼルスで初めて解明された もので，自動車から排出される炭化水素 $(\mathrm{HC})$, 窒素酸 化物 (NOx)，また工場などから排出されるNOxが，強 い太陽光線によって光化学反応を起こして，多くの複雑 な高分子化合物とオキシダント（主としてオゾン）を生 じ，これが視程障害となってスモッグを起こすものであ ります。

東京で話題となっている光化学スモッグ問題は，ロサ ンゼルスの場合と比べて発生の仕方が違うこと，湿度が 高いこと，HC濃度が低いことなどの点で異なってお り，また一部には $\mathrm{S} \mathrm{O}_{2}$ などを主原因とする硫酸ミスト と混同した見方もあるので，事態の究明と適切な対策が 必要であります (表 9 ).

表 9 東京のオキシダント注意報・警報 7 月27日から発令

オキシダント 注意警報 都民への呼びかけ
度

$0.15 \mathrm{ppm} / \mathrm{h}$ 注 意 報 (1)屋外に出ない （風速 $3 \mathrm{~m}$ 以下）

(2)自動車をなるべく使わ ない

(3)自家用車は相乗りする

(4)目に刺激を受けたら保 健所一連絡

$0.3 \mathrm{ppm} / \mathrm{h}$ 警 報 (1)屋外運動をやめる

(2) $\mathrm{SO}_{2}$ 排出工場に自肃要 請

(3)外出は電車利用

(4)目，呼吸器などの自覚 症状があったら保健所 几連絡

* 東京が，ロサンゼルスより厳しい基準を採用してい るのは，わが国の $\mathrm{SO}_{2}$ 污染度が高く，しかも高温高 湿で硫酸ミストが発生しやすいなど他の要因を考虑 したものであると説明されている。

ロサンゼルスのオキシダント警報

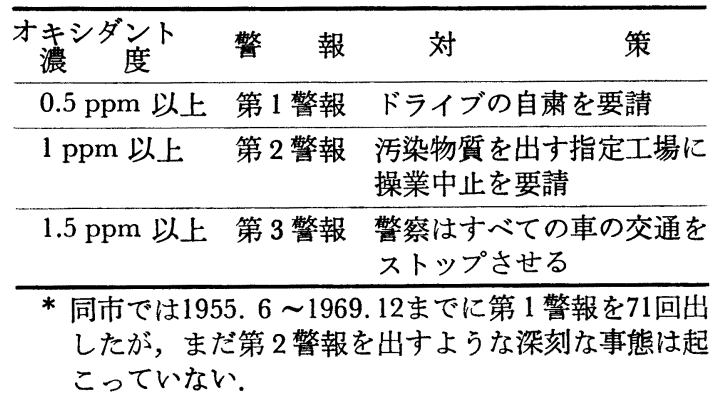

\section{4 局地污染}

局地污染として代表的な一酸化炭素 $(\mathrm{CO})$ 污染は, 自 動車を主原因とします．自動車排気ガス中のCO規制に ついては，わが国では昭和41年より生産車について世界 的にも厳しい規制が実施され，さらに昨年 8 月には既販 車にもアイドルCO規制が適用され，その効果が期待さ れています。

\section{5 わが国の規制}

大気清浄化のためには，もちろんすべての発生源につ いて対策がなされなければならないが，自動車に関して は，運輸技術審議会が自動車排出ガス規制計画を提案し ています。それによると，昭和50年までに昭和38年当時 の空気を，昭和55年までに昭和36年当時の空気を取戻す ことを目標としています. 昭和44年の排出ガス量を基準 （1.0）としますと，表10のようになり，大気清浄化に大 きく寄与することが期待されています。

表10

\begin{tabular}{|c|c|c|c|}
\hline & 昭 和 44 年 & 昭 和 50 年 & 昭 和 55 年 \\
\hline $\mathrm{CO}$ & 1.0 基準値 & 0.6 & 0.5 \\
\hline $\mathrm{HG}$ & 1.0基準值 & 0.6 & 0.1 \\
\hline NOx & 1.0基準值 & 1.0 & 0.3 \\
\hline
\end{tabular}

\section{6 アメリカの規制值}

アメリカの規制值は表11に示してあります。このうち 第 3 段にあるマスキー法案というのは，本来1980年を目 標とした值であったが，マスキー氏により実施時期を 5 年縮められたもので，その実現の可能性について問題を 含んで扔ります。この值は，ある運転モードによってシ ヤシーダイナモ上の值で mile 相当の運転に対し，何グ ラムを出すかという值であります。

表11 米国自動車排気ガスの規制 (単位 $\mathrm{g} / \mathrm{mile}$ )

\begin{tabular}{lcccc}
\hline & & NOx & $\mathrm{GO}$ & $\mathrm{HG}$ \\
\hline 無 $\quad$ 対 & 策 & 6.0 & 80 & 18 \\
19771 年 & 4.0 & 23 & 1.5 \\
マスキー法(1975年) & 3.0 & 4.7 & 0.46 \\
マスキー法(1976年) & 0.4 & 4.7 & 0.46 \\
\hline
\end{tabular}

\section{7 清浄化対策}

燃焼の吟味はキャブレータまたは電子制御燃料噴射装 置，点火時期などで行なわれます，主としてNOガスの 排出を制限する方策に研究が集中されています。

排気再循環方式はNO対策であります，エンジンから 出た排気を清浄にするためには，(1)マニフォードルリア クター，(2)アフターバーナー，(3)触媒マフラーなどがあ り，これらの単独または組合わせで一つのシステムをつ 


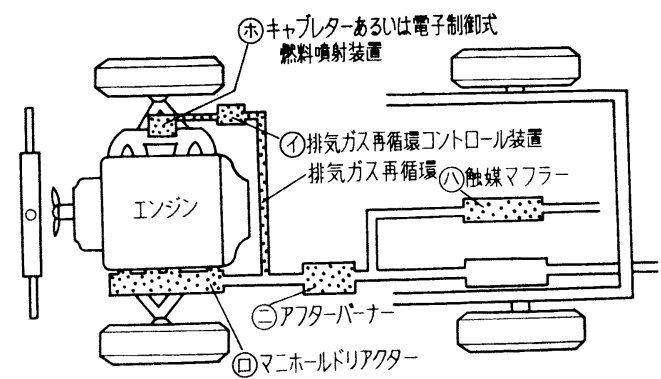

図 8 排出ガス浄化装置各種

（注）五つの方式は，並行して開発がすすめられている が，実用化される場合には，単独あるいは組合せに よって使用される。

くります，なお(1)，(2)，(3)の配固もいろいろなことが考 えられ，図 8 は単に説明用のものであります.

公害問題は規制によって研究開発の完成すべき時期が きまっており，しかも非常にむずかしい問題であります が，期日内に解決しなければならないと思っています。

\section{5. 安全問題と道路}

交通事故は最近のモータリゼーションの影響をうけて 増加の一途をたどっています。この解決には都市計画か ら救急医療に至るまで，すこぶる広範囲な対策を必要と しますが，今日は道路と車両自身について述べることに します。

\section{1 交通事故}

交通事故による死亡者は，昨年度は史上最悪で16,765 人でございました，軽微な事故も加えますと，死傷者合 計で 100 万人弱あったのであります，本年は年初以来各 万面の努力が実りまして，ただいまのところ増加の傾向

表12 主要国の交通事故発生状況

\begin{tabular}{|c|c|c|c|}
\hline 国 & 名（年次） & 死 者 数 & $\begin{array}{l}\text { 自動車保有 } 1 \text { 万 } \\
\text { 台当り死者数 }\end{array}$ \\
\hline 日 & 本（昭和 45 年） & 16,765 人 & 9人/万台 \\
\hline アメリ & 力 ( $")$ & 55,300 & 5 \\
\hline イギリ & ス（昭和44年） & 7,380 & 6 \\
\hline フラン & र (") & 14,700 & 11 \\
\hline 西ドイ & ツ( & 16,580 & 12 \\
\hline
\end{tabular}

凟料：警察庁交通事故年報, I R F 世界道路統計他

をくいとめられるような状勢ですが，予断をゆるしませ h.

\section{2 道路事情}

道路事情につきましては図 9に各国の道路比較を示し ました，高速道路の延長でも，舗装率でも，各国に比し 著しい見劣りのするのがおわかりと思います。
高速道路の延長 1970.1. 現在 (日本し1970.3.) (単位: $\mathrm{km}$ )

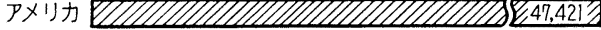
イギリス U1.037习
フランス ए1111,305

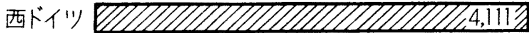

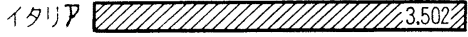
日 本
道路の哺淁率 1967.12. 現在（日本は1970.3.）

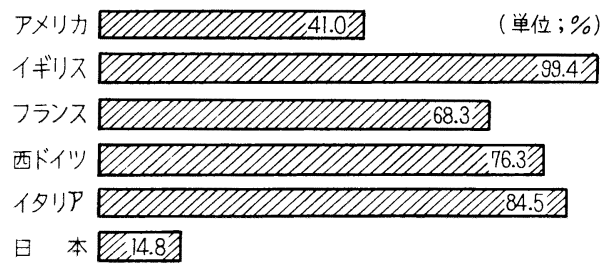

図 9 各国の道路比較 資料 : 建設省明日をひらく道路

図10には道路投資の推移を示しました．この図でもお わかりいただきますように，わが国の投資はきわめて近 年になって発展したばかりであります。

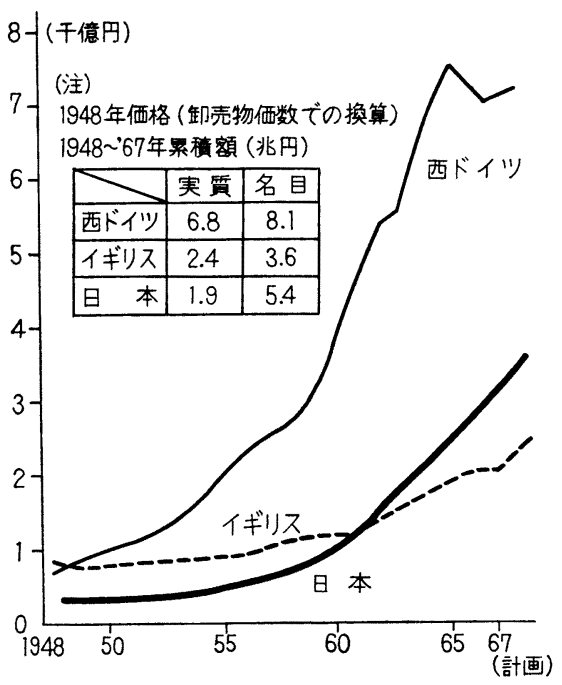

図10 道路投資額の推移

資料：IRE Staff Report, Basic Road Statistics，道路 '68/5，外国経済統計年報（建設省）

図11は道路原単位を示します，政府は 45年 60年にか けまして，道路整備長期計画をたて，これによりますと 60 兆円を投資し，その結果図11のように昭和 47 年頃が最 悪で，以後逐次改善され，昭和60年には昭和37年頃の状 況にまで改善されます。 


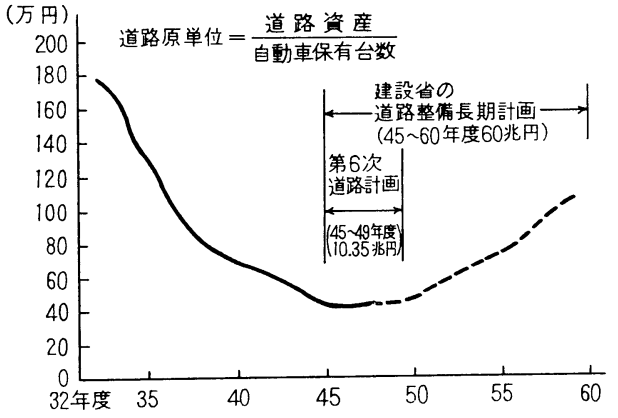

図11 道路原単位の推移（43年度価格）

資料：建設省調べ（45.5）ただし自動車保有台数は, 自工会統計月報，需要予測他

図12は高速道路と一般道路の比較で，これで打孙り いただけますように高速道路の安全率が高いのでありま す. 都市にも $60 \mathrm{~km} \sim 70 \mathrm{~km}$ の自動車専用道路を作るこ とは，肝要なことでありまして，東京，大阪などの事故 が減少傾向にあることからも推定できます。

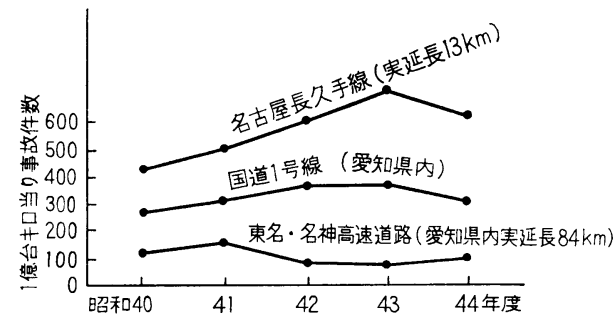

図12高速道路扮よび一般国道に扝ける走行台キ口 当りの事故件数

資料：愛知県警交通統計昭和 44 年，名神警放課交通統 計昭和45年10月より

秩序というものは，自動車が超閑散のときには必要が 少なく，また超過多のときには自然整然たる秩序がで きます，その関係を示したのが図13であります。

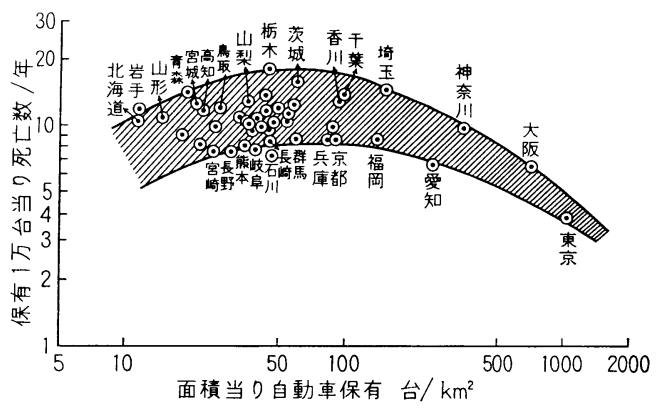

図13自動車の密度と交通事故死亡数（1970年）

東京は, 面積 $1 \mathrm{~km}^{2}$ 当り自動車の数は 1 千台を越して
いるのですが，自動車保有 1 万台当り死亡者数は 3.8人 と少なく（全国平均は 9人)，大阪，愛知，神奈川なども 少なく，また，岩手，北海道といった所でも比較的少な いのですが，東京周辺の県では，非常に死亡率が高いの であります。

\section{6. 安全と自動車}

\section{1 自動車の保有はどこまでふえるか}

図に示しますように，現在 1,900 万台（本年 3 月末） の自動車保有はどこまでのびるかを考えてみますと，大 体 3,000万台〜 4,000万台と考えられるのであります (図14).

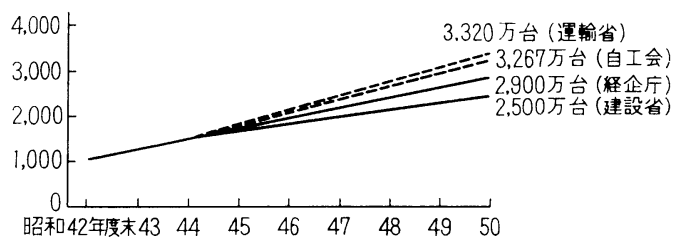

図14 自動車保有台数の見通し

\section{2 日本における安全対策}

自動車メーカーは安全対策に積極的に取組んでおりま す。また保安基準む昭和43年 7 月，第一次安全対策とし て12項目，昭和44年 6 月，第二次安全対策 として 4 項 目，昭和45年，第三次安全対策として12項目の改正が行 なわれました。このため，少なくとも交通機関としての 一応の安全水準は得られたと思います。今後さらに11項 目の対策が建てられるものと思います。

\section{3 米国における安全対策}

米国に扔ける自動車事故による死亡者は 5 万 6 千人と 報告されて抢り，米国政府は10年計画で死者の $95 \%$ 低減 つまり死亡実数 2,800 人にしようという，誠に遠大な計 画を立てているのであります。とりあえず， 5 年間で半 減しょうとしています。

このような背景で，1966年に安全法が制定され，逐次 対策をうっているのであります。この安全法は(1)衝突事 故回避対策16項目，(2)衝突時の乗員保護対策14項目，(3) 衝突後の災害防止対策 2 項目から成っています。

アメリカの交通事故死の内訳は，80\%が車内死亡にな って抢り，この点が日本の $23 \%$ とは大変異なっているの であります。いかなる実用速度でも，生命を守る思想が 織込まれています，日本は各国，とりわけアメリカに大 量輸出していますので，アメリカの安全基準に合致する ことが大変急がれております。 


\section{7. むす び}

以上述べてきましたように，自動車産業をめぐる環境 は誠にきびしいものがあります。しかし，デトロイト は，きたる 10 年間に自動車の年間売上台数は，年率 3.5 \%の割合で増加し，その販売台数は1975年には 1, 130万 台，1980年には 1,320万台に達するだろうと述べていま す.これに対し，フォードのメリルは “われわれは爆弾 の上に腰かけているようなものだ”と, 将来に対して不 安を持ち, 数々の不確定要素のために, もやもやとした 不安を持っていることは否定できません.

ひるがえって, 現実はどうなっているでしょうか。こ の1月から 6 月までに, 米国では 506万台を登録しまし た. 過去最高であった1968年 480万台の記録を破り，史 上最高であり，この調子でゆけば，年間 1,000 万台突破 は確実であるといわれます ${ }^{-3)}$.もっとも，このうちアメ リカ車はこの半年間 426 万台で, 輸入車79万台となって おり，輸入車の増加割合は急ピッチとなっています。

日本はどうでしょうか.この 1 月から 6 月までに 142.4万台を登録し，前年よりわずかな増加しかありま せんが，輸出の好調に支えられ，たとえばトヨタはこの 3 月には17.6万台を生産し, 7 月には 7 万台の輸出を予 定して抢り，3月には全販売台数 18.3 万台を売り, 史上 最高を記録しているのであります。

この先はどうでしょうか.、ばらの道は続きます. 当 分, 自動車の関係者は隠忍自重を続けるしかないと思い ます.けれども, 将来には大きな夢を持てると思ってお ります.

\section{10 年後の夢}

その頃は自動車はスッカリ変化しています. 公害に対 しては今の $1 / 10$, 交通事故死は今の $1 / 10$, 日本全国で年 間 1,600 人 (45年現在, 16,725 人), 歩行者の事故は著減, 車と人は分離道路の上を通り, 都市の中でも何本かの自 動車高架道路ができており，踏切などは見たことがない といわれるようになりたいと思います。

自動車も安全のために全貌を変えています。その間 に，白黒テレビからカラーテレビに変わったと同じよう に，現在の車から全無公害の車に大転換しており，再 び，自動車ブームのリバイバルが起こることとなるでし よう.

1970年には，世界全人口の1/3しか mobilityを楽しむ人

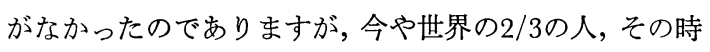
の人口を45億とすれば，30億の人が自動車を利用して， おくことの楽しみを満喫しています. そのため輸出はさ らに大きくのびるでしょう。

ああ, 自動車立国の絵巻物は，はてしなく続く.

付 記 (昭和 47 年 2 月記)

本文は昭和 46 年 5 月 19 日名古屋で行なわれた本協会の 総会の記念講演を骨子として書いたものですが，校正を 読み返してみると既に古いのです，進歩の速度の大きい のをひしひしと感じます。

昭和 46 年 8 月 16 日のニクソン声明に始まるドル・ショ ックは, 日本産業界に痛烈なショックを与えました。 同 12月には 1 ドルが 308円に決定し, 日本財界は一応平静 になっていますが予断を許しません，自動車業界は幸い にして乗りきれそうですが，第二，第三の切下げの可能 性も考えられますので長期的計画のもとに技術的戦略を 練らなければなりません.

環境問題についても, きびしさが更に増しているにも かかわらず，マスキー法の達成には十分な自信のあるも のができていません.

トヨタ自動車では，昭和46年 6 月 1 日から同年11月30 日に至る期間の事業報告書を本年 1 月に発表しました。 それによると, その期間の生産台数は 102.5 万台, 売上 金額は 5,445 億円, 従業員数は 40,918人で, 従業員 1 人 当り年間生産台数は50.6台 (眓 3 参照) となり, 259ペーシ 右で述べた44.5台がそれだけ向上したことになります. 1 人当り年間売上金額は 2,661 万円（図 4 参照）と飛躍 し，世界会社ランキングではGM，フォードに次ぐ第 3 位となりました (表 2 参照)。このような好調にもかか わらず，自動車業界はたくさんの厳しい問題をかかえ， 本年は勝負の年とも言われており，本文はいささか楽観 的のよらに反省されます。それだけにまたやりがいを見 出すのです. 最後に私の処世訓をあげさせていただきま 于.

花は愛惜のうちに散り, 雑草は憎まれつつも 茂い繁る。ここから人生のすばらしさが生ま れる.

\section{9. 参 考 文 献}

1）自動車技術 19, No. 1 (昭40. 1)

2) 自動車技術 25, No. 3 (昭46. 3)

3）プレジデント 9, 52, No.6（昭46. 6) 